\title{
ANALISIS FAKTOR DETERMINAN YANG MEMPENGARUHI PROFESIONALITAS GURU BIDANG STUDI ILMU SOSIAL DI KOTA PAREPARE
}

\author{
Afrilya Liliani Pabubung ${ }^{1 *}$, Muhammad Rakib², Rahmatullah ${ }^{3}$ \\ ${ }^{1}$ Pendidikan Ilmu Sosial, Pascasarjana Universitas Negeri Makassar \\ Email : afril.mop@gmail.com \\ ${ }^{2}$ Pendidikan Ekonomi, Universitas Negeri Makassar \\ Email: rakib_feunm@yahoo.com \\ ${ }^{3}$ Pendidikan Ekonomi, Universitas Negeri makassar \\ Email:rahmatullah@unm.ac.id \\ *Corresponding author
}

\begin{abstract}
This study aims to study educational background, teaching experience, training (education and training), and facilities on the motivation teachers, to find out their educational background, teaching experience, training (training), facilities and infrastructure, motivation of teachers towards the professionalism of teachers and to understand the educational background, teaching experience, training (training), and infrastructure for teacher professionalism through social science teachers in the Municipality of Parepare.This research is quantitative research, a type of correlational research. The data obtained were analyzed by two types of statistics, namely descriptive statistics and inferential statistics: Data Normality Test and Hypothesis Test.The results showed that: (i) there was a direct significant influence, teaching experience, training (training), and infrastructure directly related to the motivation of teachers Parepare City, (ii) educational background, teaching experience, training, facilities and infrastructure, and direct teacher motivation on the professionalism of teachers in Parepare City, (iii) educational background, teaching experience, training (training), and indirect infrastructure facilities for teacher professionalism through social science teachers in Pare-pare City
\end{abstract}

Keywords: Influence; Educational background; Teaching experience; Training; Infrastructure; Motivation; and Professionalism.

\begin{abstract}
Abstrak. Penelitian ini bertujuan untuk mengetahui pengaruh latar belakang pendidikan, pengalaman mengajar, pelatihan (diklat), dan sarana prasarana terhadap motivasi, untuk mengetahui pengaruh latar belakang pendidikan, pengalaman mengajar, pelatihan (diklat), sarana prasarana, motivasi guru terhadap profesionalitas dan untuk mengetahui pengaruh latar belakang pendidikan, pengalaman mengajar, pelatihan (diklat), dan sarana prasarana terhadap profesionalitas guru melalui motivasi guru. Penelitian ini adalah penelitian adalah pendekatan kuantitatif, jenis penelitian korelasional. Data yang diperoleh dianalisis dengan dua jenis statistik yaitu statistik deskriptif dan statistik inferensial meliputi: Uji Normalitas Data dan Uji Hipotesis. Hasil penelitian menunjukkan bahwa: (i) terdapat pengaruh signifikan secara langsung, pengalaman mengajar, pelatihan (diklat), dan sarana prasarana berpengaruh langsung terhadap motivasi guru bidang ilmu sosial di Kota Parepare (ii) latar belakang pendidikan, pengalaman mengajar, pelatihan (diklat), sarana prasarana, dan motivasi guru berpengaruh langsung terhadap profesionalitas guru bidang ilmu sosial di Kota Parepare, (iii) latar belakang pendidikan, pengalaman mengajar, pelatihan (diklat), dan sarana prasarana berpengaruh tidak langsung terhadap profesionalitas guru melalui motivasi guru bidang ilmu sosial di Kota Parepare
\end{abstract}

Kata Kunci: Pengaruh; latar belakang pendidikan; pengalaman mengajar; pelatihan; sarana prasarana; motivasi; dan profesionalitas. 


\section{PENDAHULUAN}

Pendidikan memiliki peran yang strategis dalam mewujudkan pembangunan nasional. Peran itu dapat diwujudkan melalui pembelajaran-pembelajaran yang berkualitas, salah satunya adalah ketersediaan tenaga guru yang profesional. Dalam upaya peningkatan kualitas pendidikan nasional, diperlukan pendidik dalam jumlah yang memadai dengan standar mutu kompetensi dan profesional yang mempuni. Untuk mencapai jumlah pendidik profesional yang mencakupi dan dapat menggerakkan dinamika kemajuan pendidikan nasional diperlukan suatu proses yang berkesinambungan, tepat sasaran, dan efektif. Dalam kenyataannya, masih ada guru yang belum memenuhi syarat untuk disebut profesional.

Berdasarkan prinsip profesionalitas guru yang mengemukakan bahwa pendidik harus memiliki kualifikasi akademik dan latar belakang pendidikan sesuai dengan bidang tugas. Disamping itu guru juga wajib mengembangkan profesionalitasnya melaui berbagai macam pelatihan untuk menunjang kemampuannya, mampu memanfaatkan sarana prasarana dan memiliki motivasi yang baik dalam melakanakan tugas sebagai guru yang memiliki profesionalitas yang baik. Selain latar belakang pendidikan, pengalaman mengajar guru juga menentukan profesionalitas pendidik dalam mengajar. Semakin banyak pengalaman mengajar guru, maka semakin banyak pula pengetahuan-pengetahuan yang dimiliki.

Melihat berbagai faktor-faktor yang telah dibahas tentunya ada faktor yang paling menentukan profesionalitas dan menjadi determinan dalam profesionalitas guru. Dari uraian tersebut diharapkan profesionalitas guru dapat menjadi hal pokok yang perlu diperhatikan terkait dengan latar belakang pendidikan, pengalaman mengajar, pelatihan (diklat), motivasi guru dan sarana prasarana.

Tujuan yang ingin dicapai dalam penelitian ini adalah :

Untuk mengetahui pengaruh latar belakang pendidikan, pengalaman mengajar, pelatihan (diklat), dan sarana prasarana terhadap motivasi guru bidang ilmu sosial di Kota Parepare, serta untuk mengetahui pengaruh latar belakang pendidikan, pengalaman mengajar, pelatihan (diklat), sarana prasarana, motivasi guru terhadap profesionalitas guru bidang ilmu sosial di Kota Parepare.
Untuk mengetahui pengaruh latar belakang pendidikan, pengalaman mengajar, pelatihan (diklat), dan sarana prasarana terhadap profesionalitas guru melalui motivasi guru bidang ilmu sosial di Kota Parepare.

\section{METODE}

Penelitian ini menggunakan metode penelitian korelasi untuk mengkorelasikan antara latar belakang pendidikan, pengalaman kerja, pelatihan (diklat), sarana prasarana, dan motivasi guru dengan profesionalisme guru. Jenis analisis yang digunakan dalam penelitian ini adalah analisis korelasi berganda yang bertujuan untuk mengetahui tingkat asosiasi (hubungan) beberapa variabel bebas terhadap variabel terikat. Penelitian dilakukan di SMP dan SMA se-Kota Parepare dimulai bulan Maret 2018 sampai dengan April 2018 dengan populasi 114 guru dan melalui rumus sloven ditaris sampel sebesar 89 guru.

Teknik pengumpulan data pada penelitian ini adalah dokumentasi dan angket. Setelah data terkumpul, maka data tersebut perlu dianalisis terlebih dahulu secara benar dalam rangka menguji kebenaran hipotesis dan juga menarik suatu kesimpulan yang merupakan jawaban yang tepat dari permasalahan yang diajukan. Data yang disajikan berupa data mentah yang diolah menggunakan teknik statistik deskriptif. Adapun dalam deskripsi data ini yang disajikan dengan bentuk distribusi frekuensi Analisis jalur (path analysis). Teknik analisis jalur akan digunakan dalam menguji besarnya sumbangan (kontribusi) yang ditunjukkan oleh koefisien jalur pada setiap diagram jalur dari hubungan kausal antar variabel X1, X2, X3, X4 terhadap X5 serta dampaknya kepada Y. Analisis korelasi dan regeresi yang merupakan dasar dari perhitungan koefisien jalur dengan bantuan komputer program SPSS versi 21.

\section{HASIL DAN PEMBAHASAN}

\section{Gambaran Latar Belakang Pendidikan Guru Bidang Ilmu Sosial di Kota Parepare}

Berdasarkan kriteria pengkategorian, maka diperoleh distribusi frekuensi latar belakang pendidikan guru bidang ilmu sosial di Kota Parepare menunjukkan bahwa pada hasil angket latar belakang pendidikan yang diberikan kepada 89 guru dikota pare-pare terdapat 56,59 mean (rata-rata), 57,00 median (nilai tengah), 55,00 mode (nilai yang paling sering muncul), 5,12 standar deviasi, 26,22 
Afrilya Liliani Pabubung, Muhammad Rakib, Rahmatullah, Analisis Faktor... 23

varians, 22,00 rentang, 43,00 nilai terendah dan 65,00 nilai tertinggi. Hal ini menunjukkan dari hasil angket latar belakang pendidikan guru berdasarkan hasil rata-rata berada pada kategori baik sekali

\section{Gambaran Pengalaman Mengajar Guru Bidang Ilmu Sosial di Kota Parepare}

Berdasarkan kriteria pengkategorian, maka diperoleh distribusi frekuensi pengalaman mengajar guru bidang ilmu sosial di Kota Parepare terdapat 60,63 mean (rata-rata), 60,46 median (nilai tengah), 60,00 mode (nilai yang paling sering muncul), 4,44 standar deviasi, 19,71 varians, 22,00 rentang, 48,00 nilai terendah dan 70,00 nilai tertinggi. Hal ini menunjukkan dari hasil angket pengalaman mengajar guru berdasarkan hasil rata-rata berada pada kategori baik sekali.

\section{Gambaran Pelatihan (Diklat) Guru Bidang Ilmu Sosial di Kota Parepare}

Berdasarkan kriteria pengkategorian, maka diperoleh 62,48 mean (rata-rata), 62,56 median (nilai tengah), 68,00 mode (nilai yang paling sering muncul), 5,95 standar deviasi, 35,39 varians, 28,00 rentang, 47,00 nilai terendah dan 75,00 nilai tertinggi. Hal ini menunjukkan dari hasil angket pelatihan (diklat) guru berdasarkan hasil rata-rata berada pada kategori baik.
27,30 varians, 26,00 rentang, 44,00 nilai terendah dan 70,00 nilai tertinggi. Hal ini menunjukkan dari hasil angket motivasi guru berdasarkan hasil rata-rata berada pada kategori baik.

\section{Gambaran Profesionalitas Guru Bidang Ilmu Sosial di Kota Parepare}

Berdasarkan kriteria pengkategorian, maka diperoleh distribusi frekuensi profesionalitas guru bidang ilmu sosial di Kota Parepare terdapat 119,24 mean (rata-rata), 119,07 median (nilai tengah), 119,00 mode (nilai yang paling sering muncul), 7,88 standar deviasi, 62,14 varians, 37,00 rentang, 98,00 nilai terendah dan 135,00 nilai tertinggi. Hal ini menunjukkan dari hasil profesionalitas guru berdasarkan hasil rata-rata berada pada kategori baik sekali.

\section{Hasil Uji Hipotesis}

Hubungan kausal langsung latar belakang pendidikan (X1), pengalaman mengajar (X2), pelatihan (diklat) (X3), sarana prasarana (X4) terhadap motivasi (X5) dengan hipotesis operasional ada pengaruh langsung latar belakang pendidikan, pengalaman mengajar, pelatihan (diklat) dan sarana prasarana terhadap motivasi.

Tabel 1. Pengaruh Langsung X1, X2, X3, dan X4 Terhadap X5

\begin{tabular}{lcc}
\hline Variabel & $\mathrm{R}$ & Signifikansi \\
\hline $\mathrm{X} 1 \longrightarrow \mathrm{X} 5$ & 0,299 & 0,002 \\
$\mathrm{X} 2 \longrightarrow \mathrm{X} 5$ & 0,571 & 0,001 \\
$\mathrm{X} 3 \longrightarrow \mathrm{X} 5$ & 0,460 & 0,001 \\
$\mathrm{X} 4 \longrightarrow \mathrm{X} 5$ & 0,225 & 0,000 \\
\hline
\end{tabular}

\section{Gambaran Sarana Prasarana Guru Bidang Ilmu Sosial di Kota Parepare}

Berdasarkan kriteria pengkategorian, maka diperoleh 24,45 mean (rata-rata), 24,57 median (nilai tengah), 25,00 mode (nilai yang paling sering muncul), 2,54 standar deviasi, 6,46 varians, 11,00 rentang, 19,00 nilai terendah dan 30,00 nilai tertinggi. Hal ini menunjukkan dari hasil sarana prasarana berdasarkan hasil rata-rata berada pada kategori baik.

\section{Gambaran Motivasi Guru Bidang Ilmu Sosial di Kota Parepare}

Berdasarkan kriteria pengkategorian, maka diperoleh 57,71 mean (rata-rata), 57,17 median (nilai tengah), 55,00 mode (nilai yang paling sering muncul), 5,22 standar deviasi,
Hubungan kausal langsung latar belakang pendidikan (X1), pengalaman mengajar (X2), pelatihan (diklat) (X3), sarana prasarana (X4) dan motivasi (X5) terhadap profesionalitas guru $(\mathrm{Y})$ dengan hipotesis ada pengaruh langsung latar belakang pendidikan, pengalaman mengajar, pelatihan (diklat), sarana prasarana dan motivasi terhadap profesionalitas guru. 
Afrilya Liliani Pabubung, Muhammad Rakib, Rahmatullah, Analisis Faktor... 24

Tabel 2. Pengaruh Langsung X1, X2, X3, X4 dan X5 terhadap Y

\begin{tabular}{lcc}
\hline Variabel & $\mathrm{R}$ & Signifikansi \\
\hline $\mathrm{X} 1 \longrightarrow \mathrm{Y}$ & 0,541 & 0,000 \\
$\mathrm{X} 2 \longrightarrow \mathrm{Y}$ & 0,154 & 0,000 \\
$\mathrm{X} 3 \longrightarrow \mathrm{Y}$ & 0,179 & 0,000 \\
$\mathrm{X} 4 \longrightarrow \mathrm{Y}$ & 0,072 & 0,000 \\
$\mathrm{X} 5 \longrightarrow \mathrm{Y}$ & 0,115 & 0,001 \\
\hline
\end{tabular}

Hubungan tidak langsung antara variabel latar belakang pendidikan (X1), pengalaman mengajar (X2), pelatihan (diklat) (X3) dan Sarana Prasarana (X4) terhadap profesionalitas guru (Y), melalui variabel motivasi (X5) dengan hipotesis ada pengaruh tidak langsung latar belakang pendidikan, pengalaman mengajar, pelatihan (diklat) dan sarane prasarana terhadap profesionalitas melalui motivasi.

\section{Pembahasan}

Pada pembahasan hasil penelitian akan dipaparkan berdasarkan deskripsi data dan pokok dan fungsi secara kreatif, efisien, produktif dan berkesinambungan.

b. Hasil hipotesis menunjukkan bahwa pengalaman mengajar terhadap motivasi guru, dalam hal ini terdapat pengaruh langsung, sejalan denga pendapat Gomes (2003:181) motivasi seorang pekerja melibatkan faktor individual dan faktor organisasional. Yang termasuk motivasi individual adalah kebutuhan-kebutuhan (needs), tujuan (goals), sikap, dan kemampuan.

c. Hasil hipotesis menunjukkan bahwa pelatihan diklat terhadap motivasi guru,

Tabel 3. Pengaruh Tidak Langsung X1, X2, X3, X4 terhadap Y melalui X5

\begin{tabular}{|c|c|c|c|c|}
\hline \multicolumn{3}{|c|}{ Variabel } & $\mathrm{R}$ & Keterangan \\
\hline $\mathrm{X} 1 \rightarrow \mathrm{X}^{5}$ & $\rightarrow$ & $\mathrm{Y}$ & 0,515 & Terdapat Pengaruh tidak langsung \\
\hline $\mathrm{X}_{2} \longrightarrow \mathrm{X}_{5}$ & $\rightarrow$ & Y & 0,283 & Terdapat Pengaruh tidak langsung \\
\hline $\mathrm{X} 3 \longrightarrow \mathrm{X}$ & $\rightarrow$ & Y & 0,144 & Terdapat Pengaruh tidak langsung \\
\hline $\mathrm{X} 4 \rightarrow \mathrm{X}$ & $\rightarrow$ & Y & 0,408 & Terdapat Pengaruh tidak langsung \\
\hline
\end{tabular}

pengujian hipotesis. Selanjutnya pembahasan hasil penelitian akan dikembangkan dengan mengaitkan pokok-pokok, latar belakang, teoriteori, dan penelitian terdahulu yang relevan. Pembahasan akan dibagi berdasarkan rumusan masalah yang telah ditentukan yaitu

1) Apakah latar belakang pendidikan, pengalaman mengajar, pelatihan (diklat), dan sarana prasarana berpengaruh langsung terhadap motivasi guru bidang studi ilmu sosial di Kota Parepare?

a. Hasil hipotesis menunjukkan bahwa pengaruh latar belakang pendidikan terhadap motivasi guru, dalam penelitian ini menunjukkan adanya pengaruh langsung, hal ini sejalan dengan Danim (2011:117) menyatakan bahwa motivasi diri merupakan alasan sangat personal yang mendorong guru untuk berperilaku tertentu dan merupakan panggilan jiwa, keikhlasan tanpa embelembel, kesiapan mental yang tulus, afeksi nuraniah, aktualisasi potensi alami, dan rangsangan internal yang muncul dalam diri seorang pegawai untuk mengemban tugas dalam hal ini terdapat pengaruh tidak langsung, hal ini sejalan dengan Tujuan dari motivasi menurut Hikmat adalah adalah (1) merangsang seseorang untuk bekerja dengan baik, (2) mendorong seseorang untuk bekerja lebih berprestasi, (3) mendorong seorang untuk bekerja dengan penuh tanggung jawab, (4) meningkatkan kualitas kerja

d. Hasil hipotesis menunjukkan bahwa sarana prasarana berpengaruh langsung terhadap motivasi guru bidang ilmu sosial di Kota Parepare, hal ini sejalan dengan Hikmat (2009:272) menyatakan motivasi merupakan pendorong yang sangat kuat dalam menentukan terwujudnya suatu perbuatan atau tindakan yang direncanakan. Dorongan itu dapat berupa imbalan atau adanya ancaman. Dorongan juga dapat terjadi sebagai bagian dari kesadaran jiwa yang diimbangi oleh harapan terhadap suatu yang akan dicapai. Tujuan dari motivasi menurut Hikmat adalah (1) merangsang seseorang untuk bekerja dengan baik, (2) mendorong seseorang untuk bekerja lebih berprestasi, 
(3) mendorong seorang untuk bekerja dengan penuh tanggung jawab, (4) meningkatkan kualitas kerja, (5) mengembangkan produktivitas kerja, (6) mentaati peraturan yang berlaku, (7) jera dalam melanggar aturan, (8) mengarahkan perilaku untuk mencapai tujuan, (9) mempertahankan prestasi kerja dan bersaing secara sportif.

2) Apakah latar belakang pendidikan, pengalaman mengajar, pelatihan (diklat), sarana prasarana, dan motivasi guru berpengaruh langsung terhadap profesionalitas guru bidang studi ilmu sosial di Kota Parepare?

Berdasarkan latar belakang pendidikan, pengalaman mengajar, pelatihan (diklat), sarana prasarana, dan motivasi guru yang bagus sehingga terdapat pengaruh langsung terhadap profesionalitas guru bidang ilmu sosial di Kota Parepare.

Pengaruh tersebut sejalan penelitian tedahulu yang dalam hal ini memiliki beberapa kemiripan hipotesis yakni dalam jurnal Arfina Rombe 2016 dengan judul Pengaruh Pelatihan dan Pengalaman Mengajar Terhadap Profesionalitas Guru Sekolah Menengah Pertama di Kabupaten Toraja Utara dan dalam tesis karya Hanifa Intan Desiga 2018 berjudul Pengaruh Pelatihan Guru, Budaya Literasi Guru, dan Motivasi Kerja Terhadap Profesionalitas Guru Matematika Sekolah Menengah Atas di Kabupaten Sleman berikut pemaparannya.

a. Hasil uji hipotesis menunjukkan bahwa latar belakang pendidikan berpengaruh langsung terhadap profesionalitas guru, sejalan dengan Usman (2005:19) mengemukakan bahwa "guru profesional adalah orang yang terdidik dan terlatih dengan baik. Dalam hal ini pendidikan yang dimaksud ialah latar belakang pendidikan yang sesuai dengan bidang profesi seorang guru, yaitu keguruuan dan sebidang atau sesuai dengan mata pelajaran yang diajarkan di kelas. Latar belakang pendidikan akan memberikan pengaruh yang lebih besar lagi terhadap profesionalitas dan tentunya berakibat positif terhadap hasil kinerja guru, jika latar belakang pendidikan tersebut tidak hanya diwujudkan dengan kepemilikan ijazah dan gelar akademik semata, tetapi juga diimbangi dengan tingkat kedisiplinan dan motivasi yang tinggi. b. Hasil uji hipotesis menunjukkan bahwa pengalaman mengajar berpengaruh langsung terhadap profesionalitas. Hal ini sejalan dengan hasil penelitian Eliyanto dan Wibowo (2013) bahwa pengalaman mengajar berpengaruh positif dan signifikan terhadap profesionalisme guru. Dengan demikian, dapat dikatakan bahwa semakin lama atau banyak pengalaman mengajar guru maka akan semakin tinggi pula profesionalitasnya. Ada beberapa hal juga untuk menentukan berpengalaman tidaknya seorang pegawai yang sekaligus sebagai indikator pengalaman kerja menurut (Foster, 2001) yaitu: a) Lama waktu/masa kerja. Ukuran tentang lama waktu atau masa kerja yang telah ditempuh seseorang dapat memahami tugas - tugas suatu pekerjaan dan telah melaksanakan dengan baik. b) Tingkat pengetahuan dan keterampilan yang dimiliki. Pengetahuan merujuk pada konsep, prinsip, prosedur, kebijakan atau informasi lain yang dibutuhkan oleh karyawan. Pengetahuan juga mencakup kemampuan untuk memahami dan menerapkan informasi pada tanggung jawab pekerjaan. Sedangkan keterampilan merujuk pada kemampuan fisik yang dibutuhkan untuk mencapai atau menjalankan suatu tugas atau pekerjaan. c) Penguasaan terhadap pekerjaan dan peralatan. Tingkat penguasaan seseorang dalam pelaksanaan aspek-aspek teknik peralatan dan teknik pekerjaan.

c. Hasil uji hipotesis menunjukkan bahwa pelatihan (diklat) berpengaruh langsung terhadap profesionalitas guru. Hal ini didukung dengan hasil analisis deskriptif dalam penelitian ini menunjukkan bahwa pelatihan yang diikuti guru di Kota Parepare termasuk kategori baik dilihat dari indikator yaitu lamanya pelatihan yang diikuti, tingkat pelatihan dan relevansi.

Pelatihan memiliki peran penting pada pengembangan profesional guru yang diungkapkan oleh Gob (2017) bahwa pelatihan guru dapat digunakan sebagai langkah menuju profesionalisasi. Pelatihan akan memberi kesempatan bagi guru untuk mendapatkan pengetahuan, keterampilan, dan sikap baru yang mengubah perilakunya, sehingga dapat meningkatkan prestasi siswa. Pelatihan akan memberi dampak langsung terhadap proses pendidikan secara keseluruhan sehingga guru dsarankan untuk mengikuti pelatihan untuk mengembangkan 
keterampilan yang akan membantu mengatasi tantangan pengajaran.

d. Hasil uji hipotesis menunjukkan bahwa sarana dan prasarana berpengaruh langsung terhadap profesionalitas guru. Hal ini juga terlihat bahwa sarana dan prasarana yang teredia di SMP dan SMA di Kota Parepare berada pada kategori baik dan sejalan dengan penelitian dalam jurnal oleh Robby Simanjuntak. 2015. Analisis Pengaruh Lingkungan Kerja, Supervisi Pengajaran, Kelengkapan Sarana Prasarana Terhadap Profesionalisme Guru di Sekolah Menengah Kejuruan. Sarana prasarana yang lengkap akan mendorong dan memotivasi guru dalam melakukan kegiatan belajar mengajar sehingga guru lebih mampu meningkatkan kemampuannya dalam megelolah kegiatan belajar yang menarik dan maksimal serta mampu mencapai tujuan pembelajaran yang diinginkan.

e. Hasil uji hipotesis menunjukkan bahwa motivasi berpengaruh langsung terhadap profesionalitas guru. Dalam penelitian ini juga terlihat bahwa motivasi guru di Kota Parepare khususnya yang mengajar di bidang ilmu sosial berada pada kategori baik. Motivasi sendiri memiliki dua jenis yaitu motivasi ekstrinsik dan intrinsik, diantara kedua motivasi ini motivasi intrinsik akan jauh lebih tahan lama karena berasal dari dalam diri. Motivasi sangat penting sekalipun oran memiliki pengetahuan, keterampilan, dan kemampuan tetap saja berkinerja buruk apabila tidak termotivasi untuk mencurahkan waktu dan usaha mereka untuk bekerja. Tentu saja selain dari dalam diri guru harus ada dukungan dari luar. Jasmi (2012) mengungkapkan bahwa tantangan bagi seorang manajer untuk dapat menciptakan dan apa yang mereka cari. Jika dianalogikan dengan penelitian ini maka yang dimaksud dengan manajer adalah kepala sekolah. Apabila kepala sekolah tidak mampu memotivasi karyawannya, maka sekolah akan kehilangan guru yang berharga dan pada akhirnya akan merugi.

Semakin tinggi motivasi yang dimiliki oleh seorang guru, maka akan semakin tinggi pula profesionalitas guru tersebut. Dengan adanya motivasi, guru diharapkan akan terus meningkatkan kompetensi, pengetahuan, keterampilan, dan kemampuannya sehingga akan berdampak pada profesionalitasnya dalam bekerja.

3) Apakah latar belakang pendidikan, pengalaman mengajar, pelatihan (diklat), dan sarana prasarana berpengaruh tidak langsung terhadap profesionalitas guru melalui motivasi guru bidang studi ilmu sosial di Kota Parepare?

Profesionalitas guru berpengaruh tidak langsung terhadap latar belakang pendidikan, pengalaman mengajar, pelatihan (diklat), dan sarana prasarana karena melalui motivasi guru, hal ini berpengaruh tidak langsung karena akan melalui motivasi terlebih dahulu, hal ini relevan dengan penelitian oleh Agus Kurniawan. 2017. Pengaruh Motivasi Kerja dan Kesejahteraan Guru terhadap Kompetensi Profesional Guru pada MIN Air Joman dan MIS MPI Binjai Serbangan Kabupaten Asahan dengan Hasil Penelitian Terdapat pengaruh yang signifikan Motivasi kerjaguru terhadap kompetensiprofesional gurupada MINAir Joman dan MISMPI Binjai Serbangan kabupaten Asahan yaitu 83,2 persen.Terdapat pengaruh yang signifikan Kesejahteraan Guru terhadap kompetensiprofesional guru pada MIN Air Joman dan MIS MPI Binjai Serbangan kabupaten Asahan yaitu75,3 persen.

\section{SIMPULAN DAN SARAN}

\section{Simpulan}

Berdasarkan hasil penelitian yang telah dilakukan dapat diambil kesimpulan sebagai berikut:

1. Terdapat pengaruh signifikan secara langsung, pengalaman mengajar, pelatihan (diklat), dan sarana prasarana berpengaruh langsung terhadap motivasi guru bidang ilmu sosial di Kota Parepare.

2. Latar belakang pendidikan, pengalaman mengajar, pelatihan (diklat), sarana prasarana, dan motivasi guru berpengaruh langsung terhadap profesionalitas guru bidang ilmu sosial di Kota Parepare.

3. Latar belakang pendidikan, pengalaman mengajar, pelatihan (diklat), dan sarana prasarana berpengaruh tidak langsung terhadap profesionalitas guru melalui motivasi guru bidang ilmu sosial di Kota Parepare.

\section{Saran}

1. Bagi kepala dinas pendidikan, kiranya memperhatikaan guru dalam meningkatkan profesionalitas. 
Afrilya Liliani Pabubung, Muhammad Rakib, Rahmatullah, Analisis Faktor...| 27

2. Bagi kepala sekolah, kiranya dapat melakukan pelatihan (diklat) dan menjalin kerjasama saling memotivasi yang erat dengan guru dalam meningkatkan profesionalisme guru di sekolah masingmasing.

3. Bagi guru, kiranya banyak meningkatkan pelatihan dan motivasi kerja dalam meningkatkan profesionalitas

4. Bagi peneliti lainnya, kiranya dapat meneliti lebih jauh tentang pengaruh latar belakang pendidikan, pemgalaman mengajar, pelatihan (diklat), sarana prasarana dan motivasi guru dengan profesionalitas guru bidang Ilmu Sosial.

\section{DAFTAR RUJUKAN}

Ary, Donald. 1982. Metode Penelitian. Bandung: Angkasa.

Eliyanto, Udik Budi Wibowo. 2013. Pengaruh Jenjang Pendidikan, Pelatihan, dan

Pengalaman Mengajar terhadap Profesionalisme Guru SMA Muhammadiyah di Kabupaten

Kebumen. Jurnal Akutabilitas Manajemen Pendidikan. Vol. 1 No. 1

Kurniawan, Agus. 2017. Pengaruh Motivasi Kerja dan Kesejahteraan Guru terhadap Kompetensi

Profesional Guru pada MIN Air Joman dan MIS MPI Binjai Serbangan Kabupaten Asahan. Medan: UINSU

Murwati, Hesti. 2013. "Pengaruh Sertifikasi Profesi Guru Terhadap Motivasi Kerja Dan Kinerja Guru Di Smk Negeri Se-Surakarta”. Jurnal Pendidikan Bisnis dan Ekonomi. Volume I No. 1.

Musfah, Jejen. Peningkatan Kompetensi Guru Melalui Pelatihan dan Sumber Belajar Teori dan Praktek. Jakarta: Kencana 2011

Mustofa. 2007. Upaya Pengembangan Profesionalisme Guru di Indonesia. Jurnal Ekonomidan pendidikan. Volume 4 Nomor 1. 76-80

Siagian, Sonday P. 2008. Manajemen Sumber Daya Manusia. Jakarta: PT Bumi Aksara

Simanjuntak, Robby. 2015. Analisis Pengaruh Lingkungan Kerja, Supervisi Pengajaran, dan Kelengkapan Sarana
Prasarana terhadap

Profesionalisme Guru di

Sekolah Menengah Kejuruan. Jurnal Pendidikan Vol 13 No. 3 Mei 2015

Usman, M. User. 2010. Menjadi Guru Profesional. Bandung: PT Remaja Rosda Kerja 